\title{
Forest Response to Chronic Hurricane Disturbance in Coastal New England
}

\section{Citation}

Busby, Posy E., Charles D. Canham, Glenn Motzkin, and David R. Foster. 2009. Forest response to chronic hurricane disturbance in coastal New England. Journal of Vegetation Science 20(3): 487-497.

\section{Published Version}

doi:10.1111/j.1654-1103.2009.01056.x

\section{Permanent link}

http://nrs.harvard.edu/urn-3:HUL.InstRepos:4317714

\section{Terms of Use}

This article was downloaded from Harvard University's DASH repository, and is made available under the terms and conditions applicable to Open Access Policy Articles, as set forth at http:// nrs.harvard.edu/urn-3:HUL.InstRepos:dash.current.terms-of-use\#OAP

\section{Share Your Story}

The Harvard community has made this article openly available.

Please share how this access benefits you. Submit a story.

\section{Accessibility}




\section{Forest response to chronic hurricane disturbance in coastal New England}

Posy E. Busby ${ }^{1,5}$, Charles D. Canham ${ }^{2}$, Glenn Motzkin ${ }^{1,3}$, David R. Foster ${ }^{1,4}$

${ }^{1}$ Harvard Forest, Harvard University, 324 North Main St., Petersham, MA 01366

${ }^{2}$ Cary Institute of Ecosystem Studies, Box AB, Milbrook, NY 12545

email: canhamc@ecostudies.org

3email: gmotzkin@fas.harvard.edu

${ }^{4}$ email: drfoster@fas.harvard.edu

${ }^{5}$ Corresponding Author: Posy E. Busby. Current address: Stanford University, Department of

Biology, 371 Serra Mall, Stanford CA 94305, USA; e-mail: busby@post.harvard.edu; phone:

(650) 725 - 6691; fax: (650) 723 - 6123 


\begin{abstract}
Question: Hurricanes and cyclones cause a wide range of damage to coastal forests worldwide. Most of these storms are not catastrophic in ecological terms, but forest responses to storms of moderate intensities are poorly understood. In regions with a high frequency of moderate hurricanes, how does variation in disturbance intensity affect the magnitude of ecological responses?
\end{abstract}

Location: Naushon Island, Massachusetts USA

Methods: We use historical records and dendroecological methods to characterize establishment and growth of Fagus grandifolia, Quercus alba and Quercus velutina in response to seven non-catastrophic hurricanes of varying intensity and a major logging event, relative to baseline conditions, over the past $\sim 150$ years. Our aim was to document variation in the magnitude of responses to known disturbance events of varying intensity, and to determine whether tree growth after moderate hurricanes differs from growth during periods of no disturbance.

Results: Forest harvesting in 1824-1827 had a strong impact on forest composition and growth. Since then, the study region has been characterized by little harvesting but frequent hurricanes. However, only one of the seven storms examined caused substantial increases in growth and new establishment for the dominant species; most moderate disturbances had minimal impacts on growth and regeneration dynamics. We also document highly variable responses among species to individual storms, including substantial growth decreases that may not be detected by standard analytical approaches.

Conclusions: Our results caution against the use of simple metrics such as wind speed to predict forest response to specific hurricanes, and highlight the importance of individual disturbance 
events in controlling long-term forest dynamics, even in regions characterized by high disturbance frequency. Additionally, we show that standard approaches to reconstructing disturbance history based on increases in radial growth and pulses of tree establishment are likely to underestimate the frequency of moderate disturbances.

Keywords: hurricane, moderate disturbance, windthrow, beech, Fagus grandifolia, coastal forest, dendroecology, release, oak, Quercus

\section{Introduction}

Wind storms including hurricanes, extra-tropical cyclones, tornados, and thunderstorms, cause a wide range of damage to forests worldwide. Previous studies have focused on forest response to individual wind storms at the ends of a spectrum of disturbance severity (i.e. catastrophic wind storms or individual tree-fall gaps). In contrast, the range of forest responses to wind storms of moderate intensities, including most hurricanes, is poorly understood (but see Batista \& Platt 2003; Woods 2004; Nagel \& Diaci 2006). Given the potential for increased hurricane intensity and/or frequency under future climate scenarios (Emanuel 2005; Webster et al. 2005), characterizing the range of forest responses to past hurricanes is an important first step to understanding how changing wind disturbance regimes may affect forest composition and dynamics.

Most hurricanes are moderate in intensity, causing intermediate levels of tree uprooting, crown damage, and growth change among surviving individuals, with forest response determined in part by differences in wind resistance, growth, and establishment among species (Brokaw \& Walker 1991; Bellingham et al. 1995; Batista \& Platt 2003). However, because response to wind 
disturbance is further conditioned by stand structure and composition, and environmental, meteorological, topographical, and historical factors (Webb 1989; Foster \& Boose 1992; Boose et al. 1994; Canham et al. 2001), responses to storms of any intensity can be highly variable.

Studies of forest response to disturbance have been hampered by the difficulty of determining the timing, intensity and characteristics of disturbance events over long periods. Much of the literature characterizing moderate and high-intensity disturbances has thus been based on indirect reconstructions that infer disturbance events from patterns of change in tree growth (particularly distinct "releases" in radial growth) and pulses of tree establishment (e.g. Henry \& Swan 1974; Lorimer \& Frelich 1989). This approach assumes a direct relationship between disturbance intensity, a measure of wind strength, and the magnitude of response, with more intense events eliciting more abundant release and establishment (Lorimer 1980; Frelich \& Lorimer 1991). However, because this indirect approach examines only disturbances eliciting abundant release and establishment, it fails to characterize how a broader range of disturbance intensities affects growth and regeneration dynamics relative to baseline conditions.

In this study, we avoid the potential limitations of using patterns of growth responses to infer the timing and intensity of disturbance events by examining variation in the response of coastal forests in the northeastern U.S. to known hurricanes of a range of intensities over the past 150 years. We assess the magnitude of the storms by explicitly comparing hurricane responses to growth and establishment during periods without disturbance, and to the response to a major logging event. Historical sources and a meteorological model allowed us to construct a detailed, independent, record of hurricane frequency and intensity for the study area since European colonization. These conditions present a rare opportunity to examine variation in population and species-level responses to hurricanes of varying intensities, in a region characterized by frequent 
hurricanes.

\section{Methods}

Study site

Naushon Island (12 km X $2 \mathrm{~km}$ ), located off the coast of Massachusetts, USA, was chosen for study because hurricanes are the dominant form of natural disturbance, and human land use and other natural disturbances have been minimal for the past 150 years (Busby 2008a). The island is morainal, with medium-to-coarse sandy soils (Fletcher \& Ruffinoli 1986). The last major logging event occurred in 1824-1827 and strongly affected forests in the western end of the island, as well as portions of the eastern end (Busby 2008a). Native deer have been a significant source of herbivory in forested areas throughout the historical period; however, population estimates at the time of individual hurricanes are not available.

A detailed series of maps depicting land cover change since 1780 (Des Barres) was used to identify areas of the island that have remained continuously forested. Today, Fagus grandifolia dominates all such areas, along with scattered large Quercus alba and Quercus velutina. Current stand structure varies from lower slopes of ice block depressions dominated by Fagus trees $40-70 \mathrm{~cm}$ in diameter and 20-30 m tall, to exposed ridges dominated by Fagus trees $<5 \mathrm{~m}$ tall and $<25 \mathrm{~cm}$ in diameter. Beech bark disease (BBD), a scale insect-fungus complex, has been present on the island for $>30$ years but has resulted in little mortality (D. Houston pers. comm.), in contrast with high mortality rates throughout the northeastern U.S. (Twery \& Patterson 1984; Morin et al 2006).

\section{Field data}

To characterize variation in growth and regeneration responses to specific hurricanes, we sampled vegetation in fixed-area plots $\left(400 \mathrm{~m}^{2}\right)$, subjectively located in representative examples 
of the dominant structural types across the island. Within plots $(\mathrm{N}=29)$, species and dbh were recorded for all trees $>10 \mathrm{~cm} \mathrm{dbh}$, and increment cores were taken from 15-20 trees $>7 \mathrm{~cm} \mathrm{dbh}$ for age determination and radial growth analysis. Because of the low density of Quercus spp. species in study plots, additional Quercus trees outside of study plots were also cored.

Sound cores were collected from the base (30-40 cm above the ground) of 647 trees: 433 Fagus, 146 Quercus alba, and 68 Quercus velutina. Cores were dried, mounted, and sanded to reveal the cellular structure. Tree rings were measured to the nearest $0.01 \mathrm{~mm}$ using a Velmex measuring system (East Bloomfield, NY). Cores were used to determine stand age structure for modern forests (excluding rotten cores and cores that substantially missed the pith), and to examine growth dynamics in hurricane and non-hurricane years. Sub-samples of Fagus $(\mathrm{N}=$ 92), Quercus alba $(\mathrm{N}=58)$, and Quercus velutina $(\mathrm{N}=25)$ were cross-dated (COFECHA, Holmes 1983) and used to verify results obtained using the entire sample (data not shown; Busby 2006).

\section{Hurricane regime reconstruction}

We used the HURRECON model (see Boose et al. 1994, 2001 for details of HURRECON) to reconstruct hurricane frequency and intensity (maximum sustained wind speed) for Naushon Island for 1620 - 1997. Wind speeds were then translated into a Fujita scale rating

reflecting both wind speed and estimated structural and forest damage (see Fig. 1). While actual damage assessments (e.g., for tornadoes) are typically estimated to the nearest whole Fujita value, fractional Fujita values allow for a continuous function relating wind speed and Fujita value and are useful in cases where there is a good measure or estimate of wind speed (Fujita 1985). Detailed local documentary sources also provided independent information on the extent and severity of damage to forests and structures. Based on these hurricane records, we selected 
six storms to examine that: 1) were characterized by Fujita scale ratings (F) $(1.4-2.2)$ greater than the median rating for all hurricanes (1.3), and 2) were not preceded or followed (within six years) by another hurricane (Fujita scale rating $>1$ ). For five of the six storms, written historical records document the impact of the storms in the study area. Less intense hurricanes were not included because these events were typically not recorded in historical documents, and were unlikely to have had observable effects on population-level growth dynamics. We selected hurricanes not preceded or followed by another hurricane to determine growth response to a specific event, recognizing, however, that the effects of a previous hurricane may persist longer than six years and may influence wind damage from and growth response to a subsequent storm. A longer period of separation between hurricanes was not possible given the high frequency of hurricanes. The selected hurricanes (1869, 1888, 1924, 1944, 1960 and 1991) had reconstructed Fujita scale ratings of 2.2, 1.4, 1.5, 1.9, 1.8, and 1.9, respectively (Fig. 1). An earlier hurricane $(1841,1.8)$ was also evaluated for Quercus alba, which was the only species that had sufficient numbers of stems predating this event.

\section{Growth changes in hurricane versus non-event years}

We developed an analysis that explicitly compares intraspecific variation in growth response following a hurricane to growth in non-event years. We distinguish between two types of non-event years: non-hurricane years, i.e. those that do not fall on a hurricane year, and quiet years, i.e. those that are not preceded or followed (within six years) by a hurricane with severity

$>$ F1. Because of the high frequency of hurricanes, quiet years were regularly distributed within periods that met these criteria; a greater separation between quiet years and hurricanes was not possible. We examined the same number of quiet and non-hurricane years as the number of hurricane years examined ( $N=6$ for each of the three categories). We also examined the effect 
of the 1824-27 harvesting event on Quercus alba growth. For all analyses, data from all stands were pooled, by species.

For each core, percent growth change (GC) was calculated for each hurricane and nonevent year $(t)$ using prior $\left(M_{p}\right)$ and subsequent $\left(M_{s}\right)$ ten-year growth means: $G C=\left[\left(M_{s}-M_{p}\right) /\right.$ $M_{p}$ ] x 100 (Nowacki \& Abrams 1997). We used ten-year averages to filter out short term growth responses to climate, while detecting sustained growth responses caused by disturbance (Lorimer \& Frelich 1989; Nowacki \& Abrams 1997). GC values were correlated with tree size in Fagus, with smaller trees showing greater GC. Thus, we relativized GC to account for allometric changes in growth with respect to size by multiplying GC by the diameter at year $t$. GC was not correlated with tree size for Quercus spp., and thus was not relativized for those species.

We generated GC frequency distributions for Fagus and Quercus spp. for the seven selected hurricane years, the two different sets of non-event years, and the 1824-27 logging event (Quercus alba only). Differences among GC frequency distributions following hurricane years and differences between hurricane years and non-event years are interpreted as resulting from the differential response of trees to different storms. We report standard descriptive statistics characterizing differences in GC among hurricanes, between hurricane and non-event years, and for the logging event, including: minimum and maximum, $10 \%, 25 \%, 75 \%$ and $90 \%$ quantiles, mean, median, variance, standard deviation, and skewness. The Kruskal-Wallis rank sum test and Dunns post hoc test were used to compare these values for the three categories of storm years (hurricane, non-hurricane and quiet).

In non-event years, we expected GC would be tightly distributed, with a relatively small number of individuals exhibiting above or below average growth. In response to stand-level disturbance events, in which a minimum of $25 \%$ of trees experience growth release (Nowacki \& 
Abrams 1997), we expected distributions to be more varied, with long right tails and significantly higher third quartile values relative to non-event years.

\section{Results}

Hurricane regime reconstruction

The HURRECON model identified 58 storms with landfall within the study area from 1620 to 1997 (Fig. 1). An average of 6.5 years elapsed between hurricane strikes (frequency = 0.15/year): 16 years between storms resulting in F0 damage, 13 years between F1 damage and 75 years between F2 damage. The higher frequency of hurricanes in the last century is most likely the result of increased historical and meteorological data, and is not thought to represent a real change in hurricane frequency (Boose et al. 2001). We found local historical descriptions of only 16 hurricanes affecting Naushon Island (beginning with the 1815 hurricane), including four not identified in the historical research utilized in the HURRECON reconstructions (1928, 1954, and two storms in 1955) (App. 1). The range $(0.8-2.2)$ and median (1.8) of reconstructed intensities for the storms for which we found written documentation suggest a bias toward historical documentation of higher severity storms.

Historical descriptions suggest high variability in forest damage among storms (App. 1). Descriptions of the 1944 hurricane (F1.9) indicate that it caused far more damage to forests than other storms with similar reconstructed intensities. The 1960 and 1991 storms, for example, were reconstructed as F1.8 and F1.9, but historical descriptions and field observations indicate that major damage did not occur (App. 1).

\section{Population age structure}

Fagus trees ranged in age from 26 to 204 years (median $=61$ years; $\mathrm{N}=433$ ). Fagus establishment was characterized by two major pulses - one beginning in the 1820 s that persisted 
for $>50$ years and a second following the 1944 hurricane (Fig. 2). The oldest trees in the study area were Quercus alba, which ranged from 59 to 351 years (median $=181$ years; N = 146) (Fig. 2). Quercus alba establishment began in the late 1700s, followed by a four decade period of increased establishment beginning in the 1820s. Quercus velutina establishment occurred from 1820-1860. Quercus velutina trees ranged in age from 108 to 196 years (median $=152$ years; N $=68)$ (Fig. 2).

Analysis of growth change frequency distributions

To illustrate expected differences in GC frequency distributions among hurricane and non-event years, Figure 3 compares GC frequencies in 1944 with a strongly contrasting nonevent year (1934). For Fagus and Quercus alba, the 1944 distributions have longer right tails than the 1934 distributions (Fig. 3a, b); however, the maximum GC for Fagus in 1944 was ten times greater than for Quercus alba. In 1944, most Quercus velutina exhibited negative growth responses relative to growth in 1934 (Fig. 3c).

The Kruskal-Wallis rank sum test detected no significant differences overall in the Fagus GC frequency distributions for hurricane, non-hurricane and quiet years (Table 1, App. 2). However, for Fagus, two hurricanes (1924 and 1944) had substantially higher mean, median, maximum, variance, $75 \%$ and $90 \%$ quantile values than non-event years (Fig. 4a, b). The 1960 hurricane had maximum, skewness and variance values greater than non-event years, and the 1869 hurricane had greater GC variance than non-event years (Fig. 4b).

The variance, maximum and standard deviation for Quercus alba were significantly greater in hurricane years than non-event years (Table 1, App. 2). Like Fagus, Quercus alba response to the 1944 storm was characterized by higher mean, median, standard deviation, variance, skewness, $75 \%$ and $90 \%$ quantile values than non-event years (Fig. 4a, App. 2). The 
1924 hurricane was characterized by high mean and third quartile values (Fig. 4a). Quercus velutina growth following hurricanes was significantly different from non-event years, with hurricanes characterized by the lowest 10\%, 25\% and 75\% quantiles and median values (Table 1, App. 2). However, examining individual hurricanes, only 1944 was characterized by median, maximum, variance, $10 \%, 25 \%$ and $75 \%$ quantile values lower than non-event years (Fig. 4a, c). Thus Quercus velutina behaved differently than Fagus and Quercus alba, exhibiting primarily decreased growth following hurricanes.

The logging event $(y=1826)$ resulted in a higher $75 \%$ quantile value for Quercus alba (the only species with sufficient sample size to evaluate) than any of the hurricanes (Fig. 4a). Quercus alba also had high mean, median, and 90\% quantile values in response to logging.

\section{Discussion}

Although hurricanes are relatively frequent in the study region (frequency $=0.15 /$ year), most storms in the past 150 years had minor impacts on species growth and regeneration. In fact, only one storm (1944) had substantial impacts on both growth and establishment of the dominant species. The single major timber harvest from 1824-27 also had long lasting effects on species composition and growth. Thus, our results highlight the strong influence of infrequent moderate-high severity disturbances on forest dynamics, even in regions characterized by high frequencies of disturbance. These results are consistent with previous research in temperate and tropical forests demonstrating relatively minimal response following many individual moderateintensity hurricanes (Brokaw \& Walker 1991; Bellingham et al. 1995, Batista \& Platt 2003). In addition, these results underscore the observation that response to wind disturbance is controlled by complex interactions among a wide range of meteorological, biotic, historical, and environmental conditions. Thus, disturbances of comparable intensities may result in highly 
variable patterns of damage and response depending on such factors as the previous history of disturbance and current structure of the forest.

\section{Dissimilarity in growth response to hurricanes}

For the dominant tree species, growth change for the seven hurricanes, as a group, was not significantly different from non-event years. Rather, third quartile values identified only two storms (1924 and 1944) and the logging from 1824-27 (for Quercus alba) as distinctive in their population-level effects (Fig. 4). The absence of strong impacts on tree growth following most hurricanes relative to non-event years strongly suggests that these hurricanes affected only a small percentage of trees. This interpretation is also supported by stand age structure, with establishment occurring only after the 1944 hurricane and after the 1824-27 timber harvest, and historical documentation of timber salvage following only the 1924 and 1944 hurricanes (App. 1). While we suspect that the increased tree establishment that occurred for several decades beginning in the 1820 s resulted from logging, it is possible that some trees also established in response to hurricanes in the mid $-19^{\text {th }}$ century, especially the 1841 hurricane which reportedly caused moderate damage on the island (App. 1).

Variation in growth response to hurricanes of broadly similar intensities suggests that there is not a simple relationship between hurricane intensity and the magnitude of response. Rather, species composition, stand age and height, meteorological conditions, and the time since the last disturbance strongly influence the extent to which a particular storm may result in substantial damage (Foster 1988; Webb 1989; Foster \& Boose 1992; Batista et al. 1998; Papaik \& Canham 2006). The impact of the 1944 hurricane was much greater than the impacts of other hurricanes investigated, despite similar reconstructed intensities. Given that susceptibility to windthrow increases with tree age and size (Foster \& Boose 1992; Canham et al. 2001), the 
population structure in 1944 (many trees 80-120 years of age, having established after the 1826 logging event or other disturbances in the $19^{\text {th }}$ century) may have been particularly vulnerable to storm damage. The opposite effect may have resulted in little response to the 1960 hurricane, which occurred soon after substantial removal of vulnerable overstory trees damaged by the 1944 and 1954 hurricanes. Alternatively, variation in responses may reflect dissimilarity in storm intensities. In particular, the intensity of the 1944 hurricane may have been underestimated, or others over-estimated, by HURRECON. Documentation of extensive damage elsewhere in southeastern MA following the 1944 hurricane is consistent with this interpretation (e.g. Dunwiddie 1991, Busby et al. 2008b).

Results of this study challenge estimates of the frequency and intensity of moderate disturbances derived using the standard indirect reconstruction approach (Lorimer \& Frelich 1989; Nowacki \& Abrams 1997). This approach detects only those disturbances eliciting abundant growth release and tree establishment; four of the six hurricanes examined in this study would not be identified or adequately characterized by this method. Thus, the reconstruction method is likely to underestimate the frequency of moderate disturbances that result in limited growth responses. Identifying such hurricanes is not trivial. Despite limited tree growth response, wind, salt spray and storm surges associated with these events may have important ecological impacts on soil chemistry (Blood et al. 1991), understory plant communities (Gardner et al. 1991), and animal populations (Spiller et al. 1998).

Our direct comparison of responses to known hurricanes with non-event years identified a range of species-specific responses to hurricane disturbance, including no change in growth or regeneration, greater variance in growth response relative to non-event years, both increases and decreases in growth, and greater establishment. While indirect reconstructions of disturbance 
history typically emphasize increases in growth of surviving trees as evidence of disturbance (Lorimer \& Frelich 1989; Nowacki \& Abrams 1997), our results support several studies that have documented the potential for decreased growth in response to hurricanes or other disturbances (Foster 1988; Orwig et al. 2001; Lafon \& Speer 2002; Motzkin et al. 2002).

Any method, direct or indirect, which uses trees rings to reconstruct forest disturbance history is subject to inherent limitations which must be considered when interpreting results. In particular, with age, trees become progressively less representative of the population existing at the time of past disturbance events. Thus if response (or no response) to past disturbance influences the likelihood of survival to the present, there is a potential for bias in comparisons among storms over long time periods. A second confounding factor is the constantly changing structure of forests. At different times in the past, forests were composed of individuals of differing sizes and ages whose responses to wind disturbance were likely to be affected by these demographic parameters (Foster and Boose 1992), potentially confounding comparisons among storms. However, despite these methodological limitations, tree ring analyses are extremely valuable for studies of long-term forest dynamics. In particular, our objective was to characterize tree responses to known hurricanes of varying intensities. In doing so, we show great variability in responses, most likely resulting from a combination of variation in storm intensities and stand conditions, which reveals the potential to underestimate the frequency of moderate disturbance using traditional approaches.

Species-specific growth and regeneration response to disturbance

Growth and regeneration responses to hurricane disturbance is species-specific as a result of differing biological and life-history characteristics. For instance, understory Fagus ('advanced regeneration') may respond to canopy gaps with substantial increases in growth, and 
root sprouts may develop in great abundance following above or below-ground damage (Jones \& Raynal 1986; De Steven et al. 1991; Beaudet et al. 2007). Additionally, Fagus trees unaffected by BBD, such as those evaluated in this study, are relatively resistant to wind damage (Papaik et al. 2005). This suite of traits may be important for the long-term establishment and persistence of Fagus in areas where wind disturbance is important (i.e. Russell 1953).

Fagus demonstrates extremely varied regeneration dynamics across its geographic range (cf. Kitamura \& Kawano 2001). Fagus is considered a late-successional species in northern hardwood forests where it regenerates in small canopy gaps and may live for 300 years (Ward 1961, Tubbs \& Houston 1990). In much of the northeastern U.S., most Fagus have been structurally weakened by BBD and are highly susceptible to wind damage; reduced Fagus abundance is predicted following severe wind disturbance (Papaik et al. 2005; Papaik \& Canham 2006). In contrast, our results indicate that in coastal southern New England, Fagus establishment may occur in pulses following major wind disturbance or logging, and Fagus growth increases rapidly in response to severe wind disturbance. In the southeastern U.S., Fagus persists in an environment characterized by relatively frequent moderate hurricanes, but does not increase after such storms relative to other species (Batista et al. 1998). In that region, Fagus does not re-sprout, which may help explain why a positive long term effect of hurricanes on Fagus abundance has not been observed. Thus, the combination of Fagus' pronounced shadetolerance and its flexible regeneration strategy (e.g. the ability to reproduce via seeds or root sprouts) apparently enable it to establish and persist under a wide range of site and disturbance conditions. Further studies are needed to improve our understanding of the importance of vegetative reproduction for Fagus dynamics throughout its geographic range.

Broadly similar responses to disturbance may occur among different Fagus species. In 
many European forests, $F$. sylvatica abundance has increased over the past few centuries in response to selective logging and heavy browsing of associated species (e.g., Quercus spp.). Wind disturbance may accelerate the transition to $F$. sylvatica dominance in such forests by creating small- to medium-sized gaps favoring shade-tolerant species (Pontailler et al. 1997), or by removing more susceptible conifer species (Nagel \& Diaci 2006). Similarly, F. grandifolia in our study area may have benefited from the selective harvesting of Quercus spp. in previous centuries, browsing of preferred Quercus spp. seedlings, and occasional hurricanes that resulted in increased growth and establishment of $F$. grandifolia.

Quercus spp. responded differently to hurricanes than did Fagus. While both Q. alba and Q. velutina established in the decades after the $19^{\text {th }}$ century logging event, we found no regeneration of either species following subsequent hurricanes. This result is consistent with observations suggesting that moderate wind disturbances advance the rate of succession by removing early or mid-successional canopy trees and releasing surviving shade-tolerant saplings (Webb \& Scanga 2001). However, other studies have shown that shade-intolerant species which typically do not establish in individual tree-fall gaps may colonize multiple tree-fall gaps created by moderate wind disturbance (Batista \& Platt 2003; Woods 2004). In our study area, the establishment of more shade-intolerant Quercus spp. following the 1944 hurricane may have been restricted due to competition with Fagus root sprouts (Everham \& Brokaw 1996; CooperEllis et al. 1999; Beaudet et al. 2007). Near the northern limit of Fagus' range, root sprouts grow faster than associated seedlings, allowing sprouts to exploit gaps created by storms and other disturbances (Beaudet et al. 2007). In addition, preferential herbivory of Quercus spp. seedlings by a large deer herd may have prevented Quercus spp. establishment (Raup 1945; Peterson \& Pickett 1995). 
Growth responses to hurricanes also differed among species. The magnitude of positive Q. alba GC was less than Fagus (1924 and 1944), which is consistent with observations of a greater potential for release among shade-tolerant trees (Lorimer \& Frelich 1989; Nowacki \& Abrams 1997). Importantly, hurricanes had a significant negative impact on $Q$. velutina growth (and some $Q$. alba), with periods of suppression apparently triggered by crown damage. Because, Q. alba and Q. velutina trees in modern forests were larger in 1944 than Fagus, averaging 36.7 and $40 \mathrm{~cm}$ dbh, versus $15.7 \mathrm{~cm}$ dbh for Fagus (data not shown), it is likely that the Quercus trees we sampled were in the overstory at the time of the 1944 hurricane and would have been more susceptible to crown damage than Fagus, which were likely in the understory at the time.

\section{Conclusions}

Results of this study support the notion that most hurricanes cause minimal mortality, growth change, and establishment among species (Brokaw \& Walker 1991; Bellingham et al. 1995; Batista \& Platt 2003). Only a single storm over the past 150 years caused dramatic changes in growth and establishment for the dominant species at our study sites. Intensive logging in the early $19^{\text {th }}$ century resulted in substantial regeneration of Quercus spp. and Fagus, and greater increase in growth of $Q$. alba than we observed following any of the hurricanes that we investigated. This result underscores the importance of individual disturbance events for long-term forest dynamics, even in an area characterized by frequent disturbance. Given the over-riding importance of severe disturbances, anticipated increases in the intensity of hurricanes in the North Atlantic (Emanuel 2005; Webster et al. 2005) may be expected to result in significant impacts on forest conditions and long-term dynamics.

\section{Acknowledgements}


We would like to thank Missy Holbrook, Jason McLachlan, Dave Orwig, Wyatt Oswald, Tim Warren, and anonymous reviewers for comments on earlier drafts of this manuscript. Bryan Black and Neil Pederson provided guidance on tree ring analysis. Emery Boose reconstructed the history of hurricane frequency and intensity on Naushon Island using the HURRECON model. We appreciate field assistance from John Burk, Anne Marie Casper, Brian DeGasperis, Elaine Doughty, Paul Elias, Ed Faison, Chris Graham, Brian Hall, Brooks Mathewson, Rob McDonald, Brandon McElroy, Jason McLachlan, Peter Thomas, and Jill Thompson. Paul Elias, Gon and Holly Leon, and Bruce Bagley provided valuable historical information and logistical support. Financial support for this project was provided by the National Science Foundation through the Harvard Forest Long Term Ecological Research Program, and the Harvard Graduate Student Council. This study is a contribution to the program of the Cary Institute of Ecosystem Studies.

\section{References}

Batista, W.B., Platt, W.J. \& Machiavelli, R.E. 1998. Demography of a shade-tolerant tree (Fagus grandifolia) in a hurricane disturbed forest. Ecology 79: 38-53.

Batista, W.B. \& Platt, W.J. 2003. Tree population responses to hurricane disturbance: syndromes in a south-eastern USA old-growth forest. Journal of Ecology 91: 197-212.

Beaudet, M., Brisson, J., Dominique, G., \& Messier, G. 2007. Effect of a major canopy disturbance on the coexistence of Acer saccharum and Fagus grandifolia in the understorey of an old-growth forest. Journal of Ecology 95: 458-467

Bellingham, P.J., Tanner, E.V.J. \& Healey, J.R. 1995. Damage and responsiveness of Jamaican montane tree species after disturbance by a hurricane. Ecology 76: 2562-2580. 
Blood, E.R., Anderson, P., Smith, P.A., Nybro, C., \& Ginsberg, K.A. 1991. Effects of Hurricane Hugo on coastal soil solution chemistry in South Carolina. Biotropica 23: 348-355.

Boose, E.R., Foster, D.R. \& Fluet, M. 1994. Hurricane impacts to tropical and temperate forest landscapes. Ecological Monographs 64: 369-400.

Boose, E.R., Chamberlin, K.E. \& Foster, D.R. 2001. Landscape and regional impacts of hurricanes in New England. Ecological Monographs 71: 27-48.

Brokaw, N.V.L. \& Walker, L.R. 1991. Summary of the effects of Caribbean hurricanes on vegetation. Biotropica 23: 442-447.

Busby, P.E. 2006. American beech in coastal New England: forest history and dynamics. Harvard University, MS thesis. Petersham, MA.

Busby, P.E., Motzkin, G. \& Foster, D.R. 2008a. Multiple and interacting disturbances lead to Fagus grandifolia dominance in coastal New England. Journal of the Torrey Botanical Society 135: 346-359.

Busby, P.E., Motzkin, G. \& Boose, E.R. 2008b. Landscape-level variation in forest response to hurricane disturbance across a storm track. Canadian Journal of Forest Research 38: 2942-2950.

Canham, C.D., Papaik, M.J. \& Latty, E.F. 2001. Interspecific variation in susceptibility to windthrow as a function of tree size and storm severity for northern temperate tree species. Canadian Journal of Forest Research 31: 1-10.

Cooper-Ellis, S., Foster, D.R., Carlton, C. \& Lezberg, A. 1999. Forest response to a catastrophic wind: Results from an experimental hurricane. Ecology 80: 2683-2696.

De Steven, D. Kline, J. \& Matthiae, P.E. 1991. Long-term changes in a Wisconsin Fagus-Acer forest in relation to glaze storm disturbance. Journal of Vegetation Science 2: 201-208. 
Des Barres, J.F.W. 1780. The Atlantic Neptune. Published for the use of the Royal Navy of Great Britain. Barre Publishing Co., Barre, Massachusetts.

Dunwiddie, P.W. 1991. Forest history and composition of Halfway Pond island, Plymouth County, Massachusetts. Rhodora 93: 347-360.

Emanuel, K. 2005. Increasing destructiveness of cyclones over past 30 years. Nature 436: 68688.

Everham, E.M. III \& Brokaw, N.V.L. 1996. Forest damage and recovery from catastrophic wind. Botanical Review 62: 113-185.

Fletcher, P.C. \& Roffinoli, R.J. 1986. Soil Survey of Dukes County, Massachusetts. US Department of Agriculture Soil Conservation Service. Washington, DC.

Foster, D.R. 1988. Species and stand response to catastrophic wind in central New England, U.S.A. Journal of Ecology 76: 135-151.

Foster, D.R. \& Boose, E.R. 1992. Patterns of forest damage resulting from catastrophic wind in central New England, U.S.A. Journal of Ecology 80: 79-98.

Frelich, L.E. \& Lorimer, C.G. 1991. Natural disturbance regimes in hemlock-hardwood forests of the Upper Great Lakes region. Ecological Monographs 61: 145-164.

Fujita, T.T. 1985. The downburst, macroburst and microburst. Satellite and Mesometeorology Research Project, University of Chicago, Chicago, Ill. SMRP Res. Pap. 210.

Gardner, I.R., Michener, W.K., Blood, E.R., Williams, T.M., Lipscomb, D.J., \& Jefferson, W.H. 1991. Ecological impacts of Hurricane Hugo - salinization of a coastal forest. Journal of Coastal Research 8: 301-317. 
Henry, J.D. \& Swan, J.M.A. 1974. Reconstructing forest history from live and dead plant material - An approach to the study of forest succession in southwest New Hampshire. Ecology 55: 772-783.

Holmes, R.L. 1983. Computer-assisted quality control in tree-ring data and measurement. TreeRing Bulletin 43: 69-78.

Jones, R.H. \& Raynal, D.J. 1986. Spatial distribution and development of root sprouts in Fagus grandifolia (Fagaceae). American Journal of Botany 73: 1723-1731.

Kitamura, K. \& Kawano S. 2001. Regional differentiation in genetic components for the American beech, Fagus grandifolia Ehrh., in relation to geologic history and mode of reproduction. Journal of Plant Research 114: 353-368.

Lafon, C.W. \& Speer, J.H. 2002. Using dendrochronology to identify major ice storm events in oak forests of southwestern Virginia. Climate Research 20: 41-54.

Lorimer, C.G. 1980. Age structure and disturbance history of a southern Appalachian virgin forest. Ecology 61: 1169-1184.

Lorimer, C.G. \& Frelich, L.E. 1989. A methodology for estimating canopy disturbance frequency and intensity in dense temperate forests. Canadian Journal of Forest Research 19: 651-663.

Merrens, E. \& Peart, D. 1992. Effects of hurricane damage on individual growth and stand structure in a hardwood forest in New Hampshire, USA. Journal of Ecology 80: 787-795.

Morin, R.S., Liebhold, A.M., Tobin, P.C., Gottschalk, K.W. \& Luzader, E. 2006. Spread of beech bark disease in the eastern United States and its relationship to regional forest composition. Canadian Journal of Forest Research 37: 726-736. 
Motzkin, G., Orwig, D.A. \& Foster, D.R. 2002. Vegetation and disturbance history of a rare dwarf pitch pine community in western New England, USA. Journal of Biogeography 29: $1455-1467$.

Nagel, T.A. \& Diaci, J. 2006. Intermediate wind disturbance in an old-growth beech-fir forest in southeastern Slovenia. Canadian Journal of Forest Research 36: 629-638.

Nowacki, G.J. \& Abrams, M.D. 1997. Radial-growth averaging criteria for reconstructing disturbance histories from presettlement-origin oaks. Ecological Monographs 67: 225249.

Orwig, D.A., Cogbill, C.V., Foster, D.R. \& O'Keefe, J.F. 2001. Variation in old-growth structure and definitions: forest dynamics on Wachusett Mountain, Massachusetts. Ecological Applications 11: 437-452.

Papaik, M.J., Canham, C.D., Latty, E.F. \& Woods, K.D. 2005. Effects of an introduced pathogen on resistance to natural disturbance: Beech bark disease and windthrow. Canadian Journal of Forest Research 35: 1832-1843.

Papaik, M.J. \& Canham, C.D. 2006. Species resistance and community response to wind disturbance in northern temperate forests. Journal of Ecology 94: 1011-1026.

Peterson, C.J. \& Pickett, S.T.A. 1995. Forest reorganization: A case study in an old growth forest catastrophic blowdown. Ecology 76: 763-774.

Pontailler, J.Y., Faille, A. \& Lemée, G. 1997. Storms drive successional dynamics in natural forests: a case study in Fontainebleau forest (France). Forest Ecology and Management 98: $1-15$.

Raup, H.M. 1945. Notes on the forests of Naushon Island. Harvard Forest Archives, HF 1945-06. Russell, N.H. 1953. The beech gaps of the Great Smoky Mountains. Ecology 34: 366-374. 
Spiller, D.A., Losos, J.B., \& Schoener, T.W. 1998. Impact of a catastrophic hurricane on island populations. Science 31: 695-697.

Tubbs, C.H. \& Houston, D.R. (1990) Fagus grandifolia Ehrh. In Silvics of North America, Vol. 2. Hardwoods. USDA FS Agricultural Handbook 654. Washington, DC.

Twery, M.J. \& Patterson, W.A. 1984. Variation in beech bark disease and its effects on species composition and structure of northern hardwood stands in central New England. Canadian Journal of Forest Research 14: 565-574.

Ward, R.T. 1961. Some aspects of the regeneration habits of the American beech. Ecology 42: 828-832.

Webb, S.L. 1989. Contrasting windstorm consequences in two forests, Itasca State Park, Minnesota. Ecology 70: 1167-1180.

Webb, S.L. \& Scanga, S.E. 2001. Windstorm disturbance without patch dynamics: twelve years of change in a Minnesota forest. Ecology 82: 893-897.

Webster, P., Holland, G., Curry, J. \& Chang, H. 2005. Changes in tropical cyclone number, duration, and intensity in a warming environment. Science 309: 1844-1846.

Woods, K.D. 2004. Intermediate disturbance in a late-successional hemlock-northern hardwood forest. Journal of Ecology 92: 464-476. 
Table 1. Kruskal-Wallis results comparing GC frequency summary statistics for hurricane $(\mathrm{H})$, non-hurricane $(\mathrm{NH})$ and quiet years $(\mathrm{Q})$.

\begin{tabular}{|c|c|c|c|c|c|c|c|c|}
\hline & \multirow[b]{2}{*}{$\begin{array}{l}\text { Fagus } \\
\text { Kruskal- } \\
\text { Wallis } \\
\text { statistic } \\
\end{array}$} & \multirow[b]{2}{*}{$\mathrm{p}$} & \multicolumn{2}{|c|}{ Quercus alba } & \multirow[b]{2}{*}{$\begin{array}{l}\text { Dunns } \\
\text { post hoc } \\
\text { test } \\
\mathrm{p}<0.05\end{array}$} & \multicolumn{2}{|c|}{ Quercus velutina } & \multirow[b]{2}{*}{$\begin{array}{l}\text { Dunns } \\
\text { post hoc } \\
\text { test } \\
\mathrm{p}<0.05 \\
\end{array}$} \\
\hline & & & $\begin{array}{l}\text { Kruskal- } \\
\text { Wallis } \\
\text { statistic }\end{array}$ & $\mathrm{p}$ & & $\begin{array}{l}\text { Kruskal- } \\
\text { Wallis } \\
\text { statistic }\end{array}$ & $\mathrm{p}$ & \\
\hline Minimum & 1.21 & 0.548 & 1.99 & 0.368 & & 4.43 & 0.109 & \\
\hline $10 \%$ Quantile & 2.39 & 0.302 & 1.22 & 0.544 & & 7.29 & $0.026 *$ & $H \& Q$ \\
\hline 25\% Quartile & 1.56 & 0.459 & 1.73 & 0.421 & & 7.63 & $0.022 *$ & $\mathrm{H} \& \mathrm{Q}$ \\
\hline 75\% Quartile & 0.328 & 0.849 & 1.07 & 0.586 & & 7.4 & $0.025^{*}$ & $\mathrm{H} \& \mathrm{Q}$ \\
\hline 90\% Quantile & 0.784 & 0.676 & 3.25 & 0.197 & & 2.85 & 0.24 & \\
\hline Maximum & 1.21 & 0.548 & 6.45 & $0.039 *$ & $H \& Q$ & 3.87 & 0.144 & \\
\hline Mean & 1.06 & 0.587 & 1.02 & 0.599 & & 5.19 & 0.075 & \\
\hline Median & 2.21 & 0.331 & 0.516 & 0.773 & & 6.63 & $0.036^{*}$ & $\mathrm{H} \& \mathrm{Q}$ \\
\hline Variance & 4.29 & 0.117 & 7.48 & $0.024 *$ & $\mathrm{H} \& \mathrm{Q}$ & 1.26 & 0.532 & \\
\hline Standard deviation & 3.24 & 0.198 & 7.17 & $0.028 *$ & $H \& Q$ & 1.28 & 0.529 & \\
\hline Skewness & 0.737 & 0.692 & 3.02 & 0.221 & & 3.17 & 0.205 & \\
\hline
\end{tabular}




\section{Figures}

\section{Fig. 1}

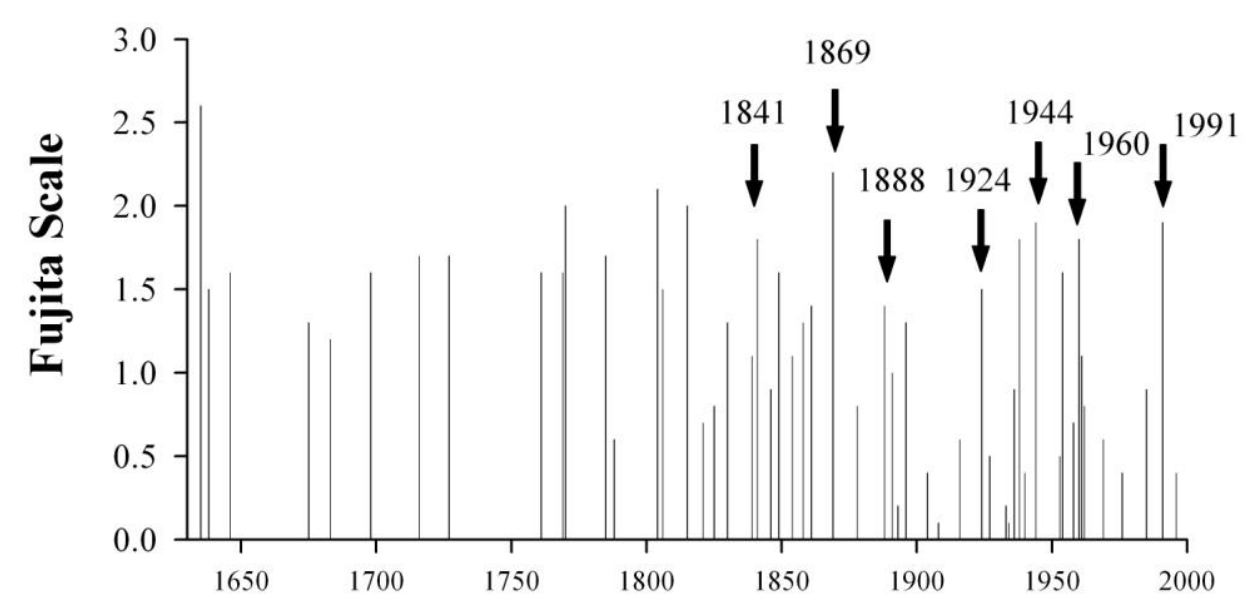

Year

1. HURRECON reconstruction of hurricanes affecting the study area (1620-1997). Arrows indicate hurricanes examined using the growth change (GC) frequency distribution analysis. F0 $=$ wind speeds $18-25 \mathrm{~m} / \mathrm{s}$, minor damage to buildings and broken branches and shallow-rooted trees uprooted; $F 1=26-35 \mathrm{~m} / \mathrm{s}$, buildings unroofed or damaged and single trees or isolated groups blown down, $\mathrm{F} 2=36-47 \mathrm{~m} / \mathrm{s}$, buildings blown down or destroyed and extensive tree blowdowns; F3 damage $=48-62 \mathrm{~m} / \mathrm{s}$, buildings blown down or destroyed and most trees blown down (see Boose et al. 1994, 2001 for details of HURRECON). 
Fig. 2

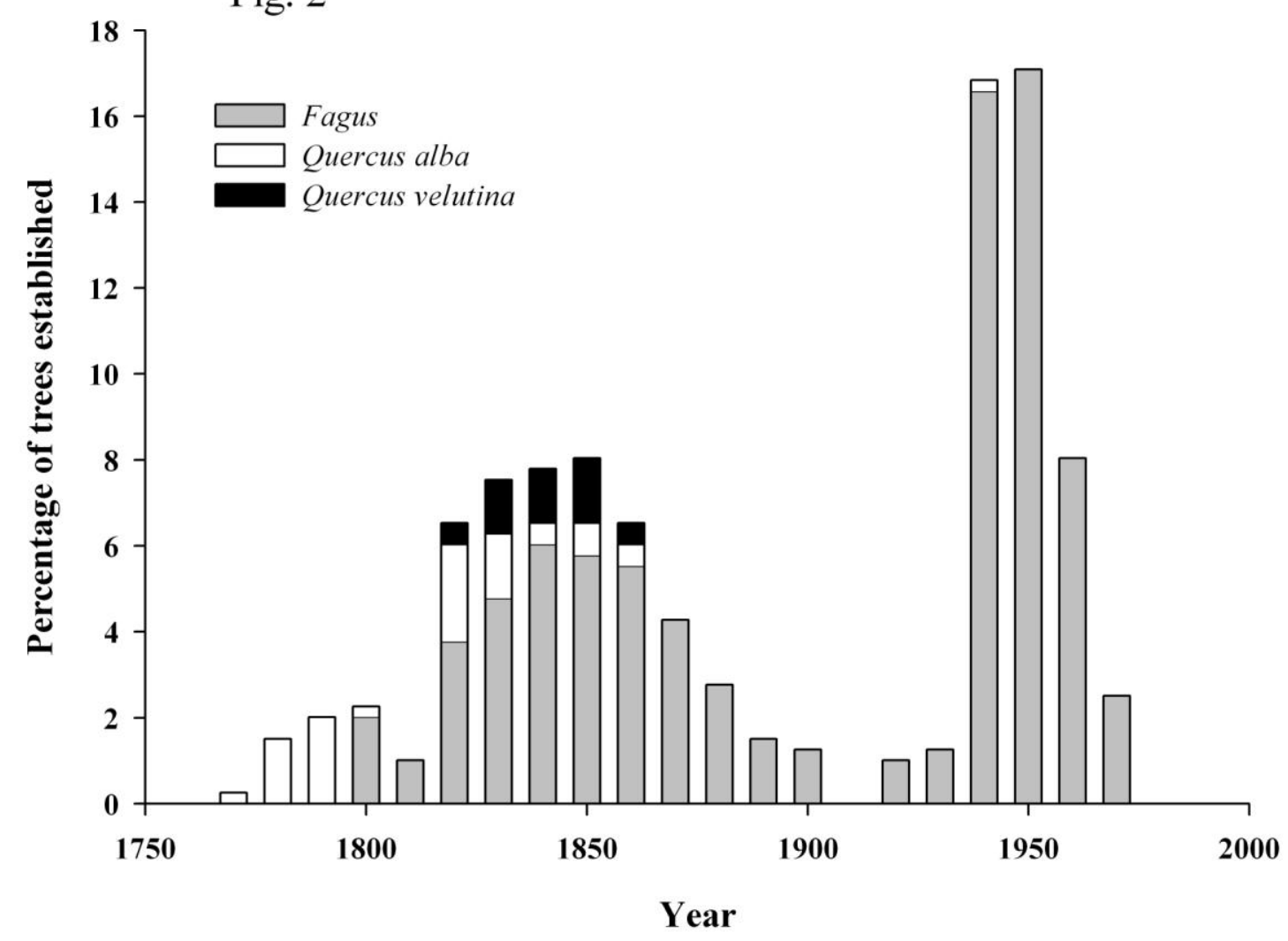

2. Age structure of trees located in study plots (Fagus $\mathrm{N}=339$, Quercus alba $\mathrm{N}=39$, Quercus velutina $\mathrm{N}=20$ ). Quercus spp. cored outside of study plots, and trees with rotten cores and cores that substantially missed the pith, are excluded. Tree establishment dates are binned by decade. 


\section{Fig. 3}

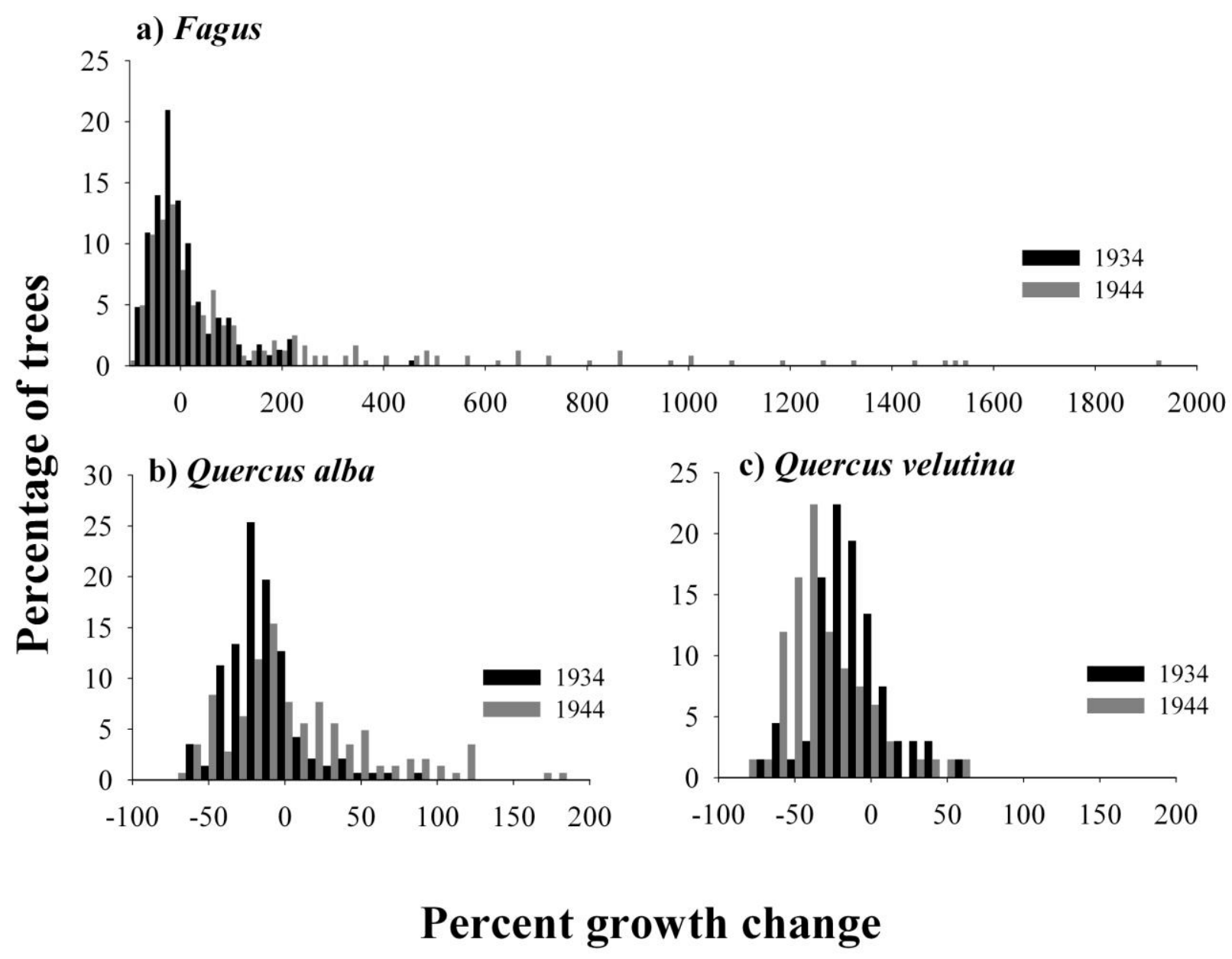

3. Growth change (GC) frequency distributions for Fagus $(1934 \mathrm{~N}=230,1944 \mathrm{~N}=246)$, Quercus alba $(1934 \mathrm{~N}=142,1944 \mathrm{~N}=143)$ and Quercus velutina $(1934 \mathrm{~N}=67,1944 \mathrm{~N}=68)$ for a hurricane (1944) and a strongly contrasting non-event year (1934). Although percent growth change for Fagus was standardized for the analysis (App. 2), it is not standardized for this figure to allow a comparison of the range in percent growth change among species. 
Fig. 4

a) $75 \%$ Quartile
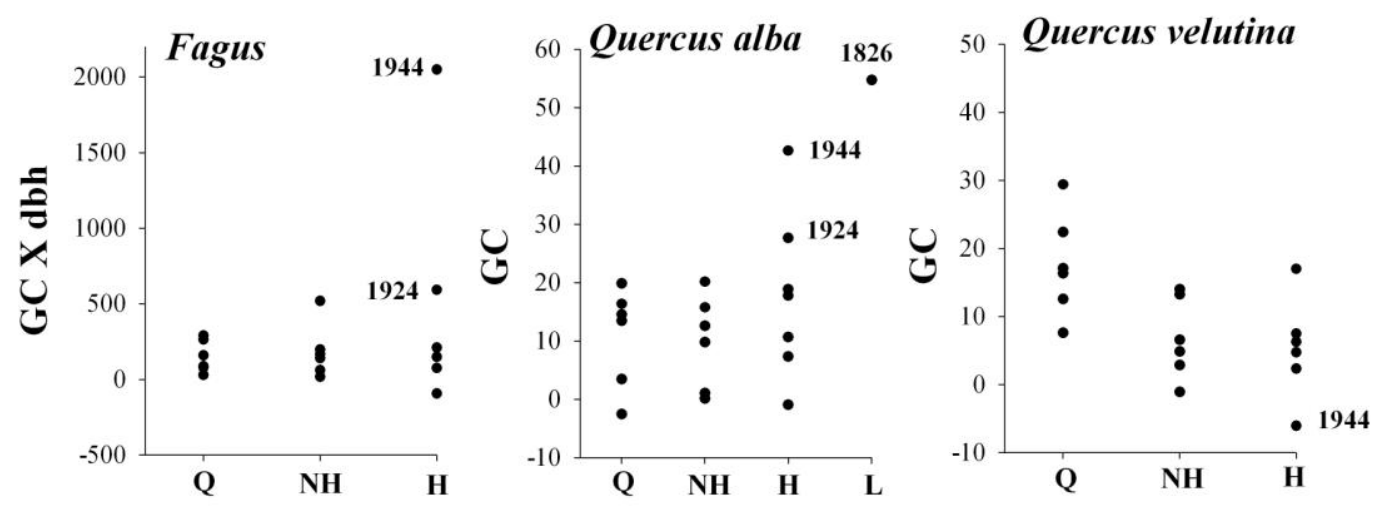

b) Variance

c) $25 \%$ Quartile
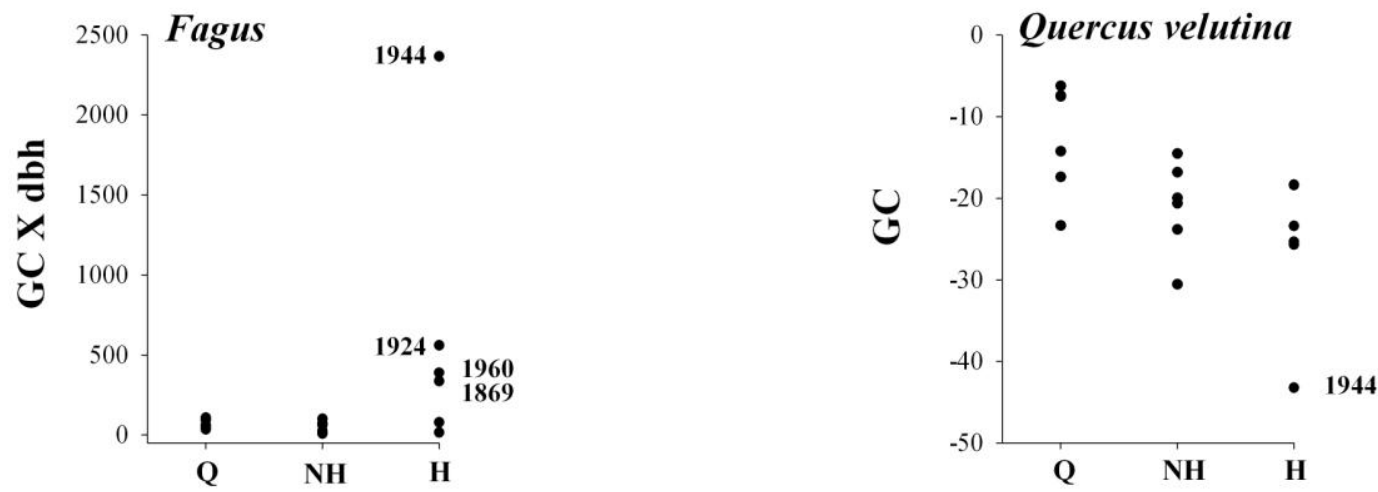

$\mathrm{Q}=$ quiet year, $\mathrm{NH}=$ non-hurricane, $\mathrm{H}=$ hurricane, $\mathrm{L}=1826$ logging event

4. Third quartile values for Fagus, Quercus alba and Quercus velutina generated in the growth change (GC) analysis. First quartile values are also shown for Quercus velutina, and variance is shown for Fagus. Categories shown on X-axis include: quiet years (Q), non-hurricane years $(\mathrm{NH})$ and hurricanes $(\mathrm{H})$. A third quartile value for the 1824-27 (y=1826) logging event, is shown for Quercus alba (L). 